of students in the study of mathematics in secondary specialized educational institutions]. Candidate's thesis. Kiev, p. 168. [in Russian].

3. Nedodatko, N. (2000). Formuvannya navchalnodoslidnytskykh umin starshoklasnykiv [Formuvannya of bulk-pre-slidnitsky mines of senior pupils]. Extended abstract of candidate's thesis. Kharkiv, p. 19. [in Ukrainian].

4. Petrovsky, A. (1976). Obshchaya psikhologiya [General psychology: textbook. for ped students. 2ed.]. Moscow, p. 479. [in Russian].
5. Stefanova, N. (2002). Problema razvitiya issledovatelskikh umeniy uchashchikhsya s pozitsii metametodicheskogo podkhoda [The problem of development of research skills of students from the standpoint of the metametodic approach]. Izvestia RGPU im. A. I. Herzen, No.3, St.Petersburg, pp. 167-175. Available at: https://cyberleninka.ru/ article/n/problema-razvitiya-issledovatelskihu men i y - u c has c hih s y a - s - pozit s i i metametodicheskogo-podhoda (accessed 27 Aug. 2020). [in Russian].

Стаття надійшла до редакції 17.05.2021

УДК 378.015.31:172.1]:355.082(045)

DOI:

Євгеній Гарбар, аспірант кафедри педагогіки, психології, початкової освіти та освітнього менеджменту

Комунального закладу “Харківська гуманітарно-педагогічна академія" Харківської обласної ради

\title{
СТРУКТУРНО-ФУНКЦОНАЛЬНА МОДЕЛЬ СИСТЕМИ ВИХОВАННЯ ГРОМАДЯНСЬКОЇ ВІДПОВІДАЛЬНОСТІ МАЙБУТНІХ ОФІЦЕРІВ ВІЙСЬКОВИХ ЗАКЛАДІВ ВИЩОЇ ОСВІТИ
}

У статті обтрунтовано структурно-функиіональну модель системи виховання громадянськоі відповідальності майбутніх офічерів військових закладів вищої освіти, складові якої структуровані, взаємопов 'язані та мають функиіональну орієнтованість. Розроблена структурно-функціональна модель містить чотири взасмопов'язаних складових: змістову, методологічну, організаційну, функціональну. Розкрито змістове наповнення кожної із них. Схарактеризовано, що результативна складова структурнофункиіональної моделі системи ГВ МО ВЗВО включає критерії, показники та рівні виховання ГВ МО ВЗВО, діагностичний інструментарій та результат. Доведено, що результатом взаємодії всіх складових структурнофункиіональноїмоделі системи виховання ГВ МО ВЗВО має стати досягнення мети, а саме: підвищення рівня вихованості громадянської відповідальності майбутніх офіџерів військових закладів вищої освіти.

Ключові слова: модель; моделювання; складові моделі; громадянська відповідальність; майбутні офічери; військові заклади вищої освіти.

Jim. 14.

Yevhenii Harbar, Postgraduate Student of the Pedagogy, Psychology, Primary Education and Education Management Department Municipal Establishment "Kharkiv Humanitarian-Pedagogical Academy"

Kharkiv Regional Council

\section{STRUCTURAL-FUNCTIONAL MODEL OF THE SYSTEM OF EDUCATION OF CIVIL RESPONSIBILITY OF FUTURE OFFICERS OF MILITARY INSTITUTIONS OF HIGHER EDUCATION}

The article substantiates the structural and functional model of the system of education of civil responsibility of future officers of military institutions of higher education, the components of which are structured, interconnected and have a functional orientation. The developed structural-functional model contains four interconnected components: semantic, methodological, organizational, functional. The content of each of them is revealed, namely: the content component (contains the social order of the state and society, purpose, object, subjects, content, components of the structure of civil responsibility of future officers and the task of education civil responsibility of future officers of military institutions of higher education); methodological component (includes methodological approaches and principles of education civil responsibility of future officers of military institutions of higher education); organizational component (covers methods, forms and means of education civil responsibility of future officers of military institutions of higher education); functional component (contains the functions and pedagogical conditions of education civil responsibility of future officers of military institutions of higher education). The 
following functions of education of civil responsibility of future officers of military institutions of higher education are allocated: information-motivational, military-professional and organizational-educational. The pedagogical conditions of education of the Ministry of Education and Science of the Ministry of Education and Science have been determined, namely: the presence of an integrated educational environment and monitoring of the level of education of the Ministry of Defense. It is characterized that the effective component of the structural-functional model of the system of civil responsibility of future officers of military institutions of higher education includes criteria, indicators and levels of education of civil responsibility of future officers of military institutions of higher education, diagnostic tools and results. Criteria apparatus (criteria and relevant indicators): motivational and acmeological (awareness of the importance of the need to educate civic responsibility; the desire to improve the level of education of their own civic responsibility; motivation for the need to educate civic responsibility); information and cognitive (the level of knowledge of the system of knowledge necessary for servicemen on the basics of civic responsibility education; the level of mastery of information and communication technologies; the level of knowledge of ethical norms of behavior of servicemen); activity-communicative (level of developed sociability; ability to prevent conflict situations; level of readiness to overcome the difficulties of military service). Levels (high, medium, sufficient). It is proved that the result of interaction of all components of the structural-functional model of the system of education of the Ministry of Defense should be the achievement of the goal, namely: to increase the level of civic responsibility of future officers of military higher education institutions.

Keywords: model; modeling; component models; civil responsibility; future officers; military institutions of higher education.

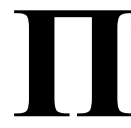

Гостановка проблеми у загальному вигляді та їі зв'язок із важливими науковими чи практичними завданнями. Пріоритетним завданням військового закладу вищої освіти, який здійснює підготовку майбутніх офіцерів, є створення усіх умов для виховання громадянської відповідальності, яка здійснюється у процесі громадянського виховання.

Сучасному суспільству потрібен новий тип військового - інтелектуальний, цілеспрямований, відповідальний, успішний, професійно грамотний, морально підготовлений, активний, творчий, самостійний офіцер 3 високим рівнем громадянської відповідальності.

Згідно з алгоритмом наукової розвідки, виникає потреба у розробці сучасної моделі системи виховання громадянської відповідальності майбутніх офіцерів військових закладів вищої освіти, яка забезпечить підвищення рівня вихованості ГВ МО ВЗВО.

Аналіз основних досліджень і публікацій. Необхідність проведення системно-структурних досліджень у педагогіці була аргументована в роботах науковців А. Арсеньєва, В. Афанасьєва, Ю. Бабанського, В. Ільїна, Ю. Конаржевського, Ф. Корольова,А. Кузнецова, В.Красвського, Б. Лихачова, Л. Новикової, В. Садовського, Ю. Сокольнікова тощо. Метод моделювання $є$ предметом широкого використання у сучасних науковопедагогічних дослідженнях (О. Біда, О. Будник, Ю. Галатюк, Н. Глузман, В. Гриньова, О. Дубасенюк, Г. Сльникова, І. Зайченко, О. Матвієнко, М. Марусинець, В. Маслов, О. Молчанюк, О. Савченко, М. Саєнко, О. Семенова, С. Сисоєва, В. Тищук, М. Фіцула, А. Харківська, Л. Хомич, В. Чайка, Х. Шапоренко та iн.).

Мета статті. Обгрунтувати структурнофункціональну модель системи виховання громадянської відповідальності майбутніх офіцерів військових закладів вищої освіти.

Виклад основного матеріалу дослідження. Для підвищення ефективності процесу виховання громадянської відповідальності майбутніх офіцерів військових закладів вищої освіти (ГВ МО ВЗВО), а також підвищення рівня вихованості ГВ МО необхідним є розроблення відповідної моделі системи.

У статті “Системний підхід та інновації в сучасній педагогічній науці” А. Харківська наголошує на тому, що в сучасних умовах розробляють такі моделі освітнього процесу, що допомагають утвердити якісно нові взаємини між його учасниками. Ці взаємини спрямовані на гуманізацію й активізацію навчально-пізнавальної діяльності суб' єктів-учасників освітнього процесу, забезпечувати інтенсивне оволодіння ними необхідного комплексу знань, умінь і навичок, а також гармонійний розвиток особистості майбутнього фахівця, сприяти адаптації його до нових умов життя [13].

Як зазначає В. Литвин, “у сучасному суспільстві універсальним засобом реалізації системи є модель як цілісне відображення реального об'єкта, в ідеальній формі, як оптимальний спосіб фіксації наукового знання" [5, 74$]$.

У контексті наукової розвідки, наведемо декілька визначень понять “модель", “моделювання”, “педагогічне моделювання”, які стануть підгрунтям у розробці моделі системи ГВ MO В3ВО.

Так, В. Краєвський вважає, що модель - це система елементів, яка відтворює деякі сторони, зв'язки, функції об'єкта дослідження [4, 333].

Натомість М. Фіцула модель визначає як “смислову” представлену і матеріально реалізовану систему, яка адекватно відображає 


\section{СТРУКТУРНО-ФУНКЦІОНАЛЬНА МОДЕЛЬ СИСТЕМИ ВИХОВАННЯ ГРОМАДЯНСЬКОӤ}

ВІДПОВІДАЛЬНОСТІ МАЙБУТНІХ ОФІЦЕРІВ ВІЙСЬКОВИХ ЗАКЛАДІВ ВИЩОЇ ОСВІТИ

предмет дослідження (наприклад, моделює оптимізацію структури навчального процесу, управління навчально-виховним процесом тощо), $\epsilon$ засобом теоретичного дослідження педагогічних явищ через уявне створення (моделювання) життєвих ситуацій; допомагає пізнати закономірність поведінки людини у різних ситуаціях" [11,32].

Модель у дослідженнях В. Штоффа, розглядається як “концептуальний інструмент, аналог певного фрагменту соціальної дійсності, що служить для зберігання та розширення знання про властивості й структуру процесів, що моделюються, орієнтований на управління ними" $[14,19]$

Моделювання розглядається дослідниками як: “вивчення певного об’єкта за допомогою спостережень або експериментів, проведених 3 його моделлю” (М. Саєнко) [8]; “процес, створення, дослідження та використання моделі” (О. Семенова) [9, 301]; “"творчий цілеспрямований процес конструктивно-проєктувальної, аналітикосинтетичної діяльності з метою відображення об'єкта в цілому або його характерних складових, які визначають функціональну спрямованість об'єкта, забезпечують йому стабільність його існування та розвитку" (Г. Сльникова) [10].

"Педагогічне моделювання" розкривається як відображення характеристик уже сформольованої педагогічної системи в спеціально створеному об'єкті” (А. Харківська) [12, 5]; науково обгрунтоване конструювання, яке відповідає заданим вимогам і наміченій побудові майбутньої моделі досліджуваного педагогічного процесу, враховуючи властивості, які вивчаються у ході педагогічного експерименту. Метою педагогічного моделювання $\epsilon$ виявлення можливостей удосконалення навчально-виховного процесу, пошуку резервів підвищення його ефективності і якості на основі аналізу моделі (С. Гончаренко) [2, 213]; уміння нестандартно організовувати навчання (пізнавальну діяльність) з будь-якого навчального предмета. Об'єднання різних видів діяльності та організація навчального процесу в межах одного уроку вимагає від учителя творчих зусиль та відповідної теоретичної підготовки (Ю. Галатюк, В. Тищук) [1, 308].

Проаналізувавши вищенаведені визначення категорії “педагогічне моделювання”, під ним будемо розуміти науково обгрунтоване конструювання, об'єднання різних видів педагогічної діяльності або досліджуваних (відповідно до теми наукової розвідки) характеристик освітньої системи в штучно розробленої моделі (схеми). Метою означеного процесу є встановлення можливостей щодо підвищення ефективності педагогічної системи загалом та освітнього процесу зокрема або встановлення ризиків, які необхідно (за наявності) усунути

Як стверджує А. Кравченя, компоненти структури повинні перебувати у взаємодії, взаємодоповнювати один одного та бути взаємопов'язаними, а в сукупності забезпечувати цілісне функціонування; зміст визначених компонентів, за потреби, може коригуватися $[3,60]$.

Нами розроблено структурно-функціональну модель системи виховання ГВ МО ВЗВО, складові якої структуровані, взаємопов'язані та мають функціональну орієнтованість. Розроблена структурно-функціональна модель містить чотири взаємопов 'язані складові: змістову, методологічну, організаційну, функціональну. Розкриємо змістове наповнення кожної із них.

1. Змістова складова містить соціальне замовлення держави та суспільства, мету, об'єкт, суб'єкти, зміст, компоненти структури ГВ МО та завдання виховання ГВ МО ВЗВО. Соціальне замовлення держави та суспільства визначено як виховання громадянської відповідальності військовослужбовців.

Мета означеної структурно-функціональної моделі системи - виховання громадянської відповідальності МО ВЗВО. Об'єкт - процес виховання військовослужбовців; суб 'єкти майбутні офіцери - курсанти ВЗВО.

Погоджуємося із А. Харківською, яка зазначає, що: “основні стратегічні пріоритети в рамках їх ринкової діяльності, сучасного нестабільного навколишнього середовища, загострення конкуренції між ними складаються в досягненні стійкого становища на ринку освітніх послуг за рахунок розробки нових напрямів розвитку освітньої діяльності, розширення асортименту послуг, що надаються" [12, 134].

Отже, мета дослідження реалізується через конкретизовані завдання.

Завданнями, які підвищують рівень вихованості ГВ МО ВЗВО за:

- мотиваційно-ціннісним компонентом ГВ MO-1)утвердження в свідомості військовослужбовців почуттів громадянина: служіння й відданості військові справі, мотивації до сумлінної служби, гордості за Батьківщину; 3) виховання поваги до командира, підлеглих, колег; 4) підняття престижності;

- когнітивно-конативним компонентом ГВ МO - вивчення 5) конституційних, нормативноправових, військових документів; 6) засад внутрішньої та зовнішньої державної політики, 
стратегічних напрямів розвитку України; 7) історії, військових ритуалів ЗСУ; 8) державної символіки, атрибути, національних традицій та звичаїв; 9) сучасних ІКТ;

- діяльнісно-вольовим компонентом ГВ МО - 10) виховання групової згуртованості МО; 11) нерепресивного спілкування МО із особовим складом; 12) формування високої військової дисципліни;

- результативно-оцінювальним компонентом структури ГВ МО -

13) сприяти усвідомленню власних прав i обов'язків як громадянина України, захисника Батьківщини; 14) виховувати активну громадянську позицію;

15) виховувати гармонійні відносини у системах “майбутній офіцер-держава”, “майбутній офіцервійськовослужбовець”, “майбутній офіцерсуспільство".

2. Методологічна складова - включає методологічні підходи та принципи виховання ГВ МО ВЗВО.

Визначивши завдання, що сприятимуть досягненню поставленої мети дослідження, обгрунтуємо методологічні підходи (системний, акмеологічний, аксіологічний, особистіснозорієнтований, культурологічний) до системи виховання ГВ МО ВЗВО: системний підхід (дозволить проаналізувати різні шляхи досягнення визначеної мети за допомогою розробки відповідної структурно-функціональної системи; системний підхід, у цьому випадку, буде виступати як засіб для розв'язання завдань наукової роботи); акмеологічний підхід (сприяє розумінню особливостей становлення та розвитку особистості майбутнього офіцера враховуючи при цьому формування його світогляду, духовності; виховання у нього активної громадянської позиції як під час служби, так і при різних політичних, соціальних, життєвих ситуаціях); аксіологічний nidxid (завдяки використанню цього підходу до досліджуваного явища у військовослужбовців виховується ціннісне ставлення до інституції влади, державної символіки, історії України, тї національних, духовних, культурних надбань, почуття патріотизму, громадянської відповідальності перед державою та суспільством, ціннісне ставлення до виконання службових обов'язків тощо); особистіснозорієнтований підхід (йому належить одна із провідних ролей у переорієнтації освітнього процесу у ВЗВО на “особистість” військовослужбовця; сприяє розвитку індивідуальних, креативних якостей ціннісносмислової професійної та громадянської діяльності. Метою особистісно орієнтованого виховання ГВ МО ВЗВО є шанобливе ставлення до культурних, духовних і матеріальних цінностей, почуття патріотизму, любові до Батьківщини, відданості військовій справі, поваги до колег, їх думок, переконань тощо); культурологічний nidxid (дозволяє розглядати процес виховання ГВ МО ВЗВО з точки зору його ціннісно-смислового розвитку як громадянина, патріота своєї Батьківщини, високоморальну особистість. Особливістю цього підходу при вихованні ГВ МО $\epsilon$ інтеграція культурних, матеріальних, духовних цінностей з військово-професійними знаннями, особистісними якостями (порядність, чесність, гідність, відданість військовій справі тощо), наукові знання й духовний досвід і спрямовує виховання на пошук людських (духовно-моральних) цінностей).

Визначивши методологічні підходи до виховання ГВ МО ВЗВО, з'ясуємо, яких принщипів необхідно дотримуватися у процесі підвищення рівня вихованості ГВ. Принципи виховання - це вихідні педагогічні положення, які тісно взаємопов'язані, слугують керівними нормами у процесі діяльності майбутнього офіцера як вихователя. Їх сукупність визначає спрямованість, зміст, організацію, методику виховання та забезпечує системний підхід до виховання ГВ МО. Ці принципи складають методологічну та організаційно-педагогічну основу виховання ГВ; одночасно закладають підгрунтя формування громадянської відповідальності майбутніх офіцерів, з одного боку, й виховання ними ГВ у підлеглих-військовослужбовців.

До принципів виховання ГВ МО ВВО відносимо:

- національної спрямованості - “передбачає формування національної самосвідомості, виховання любові до рідної землі, українського народу, шанобливого ставлення до його культури; поваги до культури всіх народів, які населяють Україну; здатності зберігати свою національну ідентичність, пишатися належністю до українського народу, брати участь у розбудові та захисті своєї держави" [7];

- самоактивності й саморегуляції-“"забезпечує розвиток у вихованця суб' єктних характеристик; формує здатність до критичності й самокритичності, до прийняття самостійних рішень; виробляє громадянську позицію особистості, почуття відповідальності за і1і реалізацію в діях та вчинках" [7];

- полікультурності - передбачає інтегрованість української культури в європейський та світовий простір, створення для цього необхідних передумов: формування відкритості, толерантного 


\section{СТРУКТУРНО-ФУНКЦІОНАЛЬНА МОДЕЛЬСИСТЕМИ ВИХОВАННЯ ГРОМАДЯНСЬКОӤ}

ВІДПОВІДАЛЬНОСТІ МАЙБУТНІХ ОФІЩЕРІВ ВІЙСЬКОВИХЗАКЛАДІВ ВИЩОЇ ОСВІТИ

ставлення до відмінних ідей, цінностей, культури, мистецтва, вірувань інших народів; здатності диференціювати спільне і відмінне в різних культурах, спроможності сприймати українську культуру як невід’ємну складову культури загальнолюдської [7];

- соціальної відповідності - зумовлює потребу узгодження змісту і методів національнопатріотичного виховання з реальною соціальною ситуацією, в якій організовується виховний процес, і має на меті виховання в дітей і молоді готовності до захисту України та ефективного розв'язання життєвих проблем [7];

- історичної і соціальної пам'яті спрямований на збереження духовно-моральної і культурноісторичної спадщини українців та відтворює іiі у реконструйованих і осучаснених формах і методах діяльності [7];

- міжпоколінної наступності, який зберігає для нащадків зразки української культури, етнокультури народів, що живуть в Україні [7];

- гуманізації і демократизації виховного процесу означає, що вся виховна робота у підрозділі підпорядковується завданням формування громадянина, захисника незалежної України [6];

- зв'язку виховання з реаліями військової служби, життям суспільства має на меті ознайомлення 3 повсякденним життям військового підрозділу, Збройних сил України, їх завданнями, з життям і діяльністю українського народу; залучення військовослужбовців до проведення заходів загального рівня (наради, проведення культмасових заходів тощо) [6];

- виховання військовослужбовця у колективі в ході спільної діяльності - реалізується на засадах соціальних та статутних відносин в колективі у процесі розв'язання завдань навчальнобойовоїпідготовки, пізнавальної діяльності [6];

- послідовності, систематичності та єдності виховних впливів - характеризується єдністю вимог командирів, колективу, батьків [6];

- свідомості, самодіяльності та активності воїнів - передбачає формування свідомої, творчої особистості воїна, вимагає його активної самодіяльності таполітичної активності [6].

Таким чином, представлені принципи ГВ МО ВЗВО сприятимуть підвищенню рівня вихованості, якщо застосовувати їх у поєднанні один із одним.

3. Організаційна складова - охоплює методи, форми та засоби виховання ГВ МО В3ВО.

Під методами виховання ГВ МО будемо розуміти сукупність способів і прийомів впливу на військовослужбовців 3 метою розвитку громадянської відповідальності як здатності особистості формувати гармонійні відносини у системах “майбутній офіцер - держава”, “майбутній офіцер -військовослужбовець", “майбутній офіцер - суспільство” використовуючи надбанні знання конституційних прав, свобод і законів держави, історії України, її традицій, та виховані особистісні якості (патріотизм, чесність, справедливість, толерантність тощо).

Отже, до методів виховання ГВ МО ВЗВО відносимо: адміністративні (накази, розпорядження, методичні рекомендації тощо) та педагогічні (групова дискусія, кейс-методи, пресс-коференції, проблемні та рольові ігри, “мозковий штурм”, професійні військові тренінги тощо).

До форм виховання ГВ МО ВЗВО включено: індивідуальні (організація та проведення бесід, консультації тощо); групові (тренінги, івенти, лінійки, вебінари, семінари-практикуми, круглі столи, екскурсії до музеїв військових частин, зустрічі із ветеранами військової служби, походи місцями бойової слави, пошукова робота тощо);

Засобами виховання ГВ МО ВЗВО є інформаційні (навчальні, навчально-методичні підручники, методичні вказівки, енциклопедії, довідникові матеріали тощо); дидактичні (інформаційні та схематичні плакати, роз'яснювальні таблиці, демонстраційні моделі тощо); технічні (аудіовізуальні засоби, IКТ, віртуальна реальність тощо).

4. Функціональна складова - містить функції та педагогічні умови виховання ГВ МО B3BO.

Грунтовне вивчення і критичний аналіз доробку вітчизняних учених (О. Бабакіної, В. Грицюка, О. Дубасенюк, А. Кобзаря, О. Копаниці, Г. Пономарьової, А. Харківської та ін.) дозволив виділити наступні функиї виховання ГВ МO $B 3 B O$ : інформаційно-мотиваційну, військовопрофесійну та організаційно-просвітницьку. Обгрунтуємо їх:

- інформаційно-мотиваційна функиія виховання ГВ МО ВЗВО забезпечує процеси збору, аналізу та обробки інформації військовопатріотичного характеру майбутніми офіцерами 3 метою формування гармонійних відносин у системах "майбутній офіцер - держава", “майбутній офіцер - військовослужбовець", “майбутній офіцер - суспільство”; підвищення рівня мотивації до виховання ГВ як власної, так і в підлеглих (активної національно-патріотичної позиції, відданості Батьківщині, поваги до іiї історії, національних, культурних, духовних надбань); впливає на процес розвитку і саморозвитку ГВ МО ВЗВО; а також усвідомлення сутності і 
значущості виконання громадянського i військового обов'язку;

- військово-професійна функиія має сприяти: систематизації загальних, професійних знань щодо основ виховання ГВ МО ВЗВО та умінь і навичок використовувати їх у процесі виконання службових обов'язків перед державою й суспільством; підвищенню рівня військової дисципліни та профілактики правопорушень; попередженню конфліктних ситуацій та подоланню складнощів військової служби;

- організаційно-просвітницькка функиія виховання ГВ МО ВЗВО полягає в організації та проведенні інформаційно-пропагандистських заходів, підвищенні результативності впливу на їх свідомість та поведінку щодо оволодіння МО системою загальних, професійних та фахових компетентностей, необхідних для виховання ГВ (патріотизму, чесності, почуття поваги до інституцій влади, захисту громадян, активної громадянської позиції тощо) у процесі освітньої, виховної та популяризаційної діяльності.

Уважаємо, що досягненню очікуваного результату сприяють також визначені педагогічні умови виховання ГВ МО ВЗВО, а саме: наявність інтегровано-просвітницького середовища та моніторинг рівня вихованості ГВ МО.

Під інтегровано-популяризачиійним середовищем будемо розуміти відкритий інформаційно-пропагандистський простір, який характеризується комплексною взаємодією та комунікаціями майбутніх офіцерів, їх командирів, працівників відповідних структурних підрозділів (системних адміністраторів, інженерів комп'ютерної техніки, провідних бібліотекарів та інших) щодо надання, опрацювання та роз'яснення відповідно відібраних, в мережі Інтернет, електронному сховищі даних ВЗВО, бібліотеці та інших центрах, матеріалів (національно-патріотичного, правового, естетичного, культурного, історичного напрямів тощо).

Під моніторингом рівня вихованості ГВ МО будемо розуміти комплекс процедур, спрямованих на збір, обробку, аналіз та поширення інформації 3 метою з'ясування реального стану рівня вихованості певного суб'єкта виховної діяльності та надання рекомендацій щодо підвищення цього рівня.

Результативна складова структурнофункціональної моделі системи ГВ МО ВЗВО включає критерії, показники та рівні виховання ГВ MO ВЗВО, діагностичний інструментарій, результат.

Критеріальний апарат - критерії та відповідні показники - мотиваційно-акмеологічний (усвідомлення значення необхідності виховання громадянської відповідальності; прагнення до вдосконалення рівня вихованості власної громадянської відповідальності; мотивація щодо необхідності виховання громадянської відповідальності); інформаиійно-пізнавальний (рівень володіння системою необхідних для військовослужбовців знань щодо основ виховання громадянської відповідальності; рівень володіння інформаційно-комунікаційними технологіями; рівень знань етичних норм поведінки військовослужбовців); діяльнісно-комунікативний (рівень розвиненої комунікабельності; здатність до попередження конфліктних ситуацій; рівень готовності долати складнощі військової служби). Pівні: високий, середній, достатній.

Діагностичний інструментарій визначення рівня вихованості ГВ МО ВЗВО представлений анкетами, тестами, опитувальниками, педагогічними ситуаціями, які були застосовані у процесі проведення педагогічного експерименту.

Висновки 3 даного дослідження i перспективи подальших розвідок у даному напрямку. Результатом взаємодії всіх складових структурно-функціональної моделі системи виховання ГВ МО ВЗВО має стати досягнення мети, а саме: підвищення рівня вихованості громадянської відповідальності майбутніх офіцерів військових закладів вищої освіти.

\section{ЛІТЕРАТУРА}

1. Галатюк Ю., Тищук В. Підготовка майбутніх учителів фізики до творчої професійної діяльності. 2005. Сер. Пед. Вип. 19. Ч. 1. С. 307-313.

2. Гончаренко С. У. Український педагогічний енциклопедичний словник. Рівне : Волинські обереги, $2011.552 \mathrm{c}$

3. Кравченя А. О. Управління якістю професійної підготовки майбутніх учителів інформатики : дис. ... канд. пед. наук : 13.00.06. Старобільськ, 2017. 260 с.

4. Краевский В., Бережнова Е. Методология педагогики: новый этап : учеб. пособие для студ. высш. учеб. заведений. Москва: Издательский центр "Академия", 2006. 400 с.

5. Литвин В. А. Виховання у майбутніх учителів початкової школи відповідального ставлення до взаємодії з сім'єю молодшого школяра : дис. ... докт. філософ. : 011 Освітні, педагогічні науки. Харків, 2021. 277 с.

6. Петренко В. М. Методика виховної роботи у військових підрозділах : підручник. Суми, 2016.475 с.

7. Проєкт Указу Президента України "Про концепцію військово-патріотичного виховання та громадського сприяння безпеці і обороні України". URL : https://www.mil.gov.ua/ministry/normativnopravova-baza/gromadske-obgovorennya/57372/proektukazu-prezidenta-ukraini-pro-konczepcziyu/. 
8. Саєнко М. С. Моделювання як метод наукового пізнання, типи моделей. URL : http://elib.umsa.edu.ua/

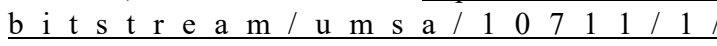
Modeluvannya yak metod naykovoho piznannya.pdf

9. Семенова О. В. Педагогічне моделювання: функції та складові. Наукові записки Бердянського державного педагогічного університету : зб. наук. пр. Випуск 3. Бердянськ, 2015. С. 299-305.

10. Теоретичні і методичні засади моделювання фахової компетентності керівників закладів освіти : монографія / Г. В. Сльникова, О. І. Зайченко, В. І. Маслов та ін. ; за ред. Г. В. Сльникової. Київ ; Чернівці : Книги XXI, 2010. 460 c.

11. Фіцула М. М. Педагогіка вищої школи : навч. посіб. Київ : Академвидав, 2010. 456 с.

12. Харківська А. А. Моделювання управління інноваційним розвитком педагогічного ВНЗ. Теорія та методика управління освітою : електрон. наук. фах. вид. / ДВНЗ “УН-т менедж. Освіти” НАПН України. 2013. Вип. 10. URL : http://nbuv.gov.ua/j-pdf/ttmuo 2013 10 47.pdf.

13. Харківська А. А. Системний підхід та інновації в сучасній педагогічній науці. Міжнародний науковий вісник : зб. наук. ст. за матеріалами XXVII Міжнар. наук. практ. конф., Ужгород - Будапешт, 26-29 листопада 2013 року. Ужгород : ДВНЗ “УжНУ”, 2014. Вип. 8 (27). С. 31-35.

14. Штофф В. А. Моделирование и философия : монография. Москва-Ленинград : наука, 1966. 303 с.

\section{REFERENCES}

1. Halatiuk, Yu. \& Tyshchuk, V. (2005). Pidhotovka maibutnikh uchyteliv fizyky do tvorchoi profesiinoi diialnosti [Preparation of future physics teachers for creative professional activity]. Pedagogy series. Vol. 19. Part. 1.pp. 307-313. [in Ukrainian].

2. Honcharenko, S. U. (2011). Ukrainskyi pedahohichnyi entsyklopedychnyi slovnyk [Ukrainian pedagogical encyclopedic dictionary]. Rivne, 552 p. [in Ukrainian].

3. Kravchenia, A. O. (2017). Upravlinnia yakistiu profesiinoi pidhotovky maibutnikh uchyteliv informatyky [Quality management of professional training of future computer science teachers]. Candidate's thesis. Starobilsk, 260 p. [in Ukrainian].

4. Kraevskiy, V. \& Berezhnova, E. (2006). Metodologiya pedagogiki: novyiy etap [Methodology of pedagogy: a new stage]. Textbook. manual for stud. higher. educat. Establishments. Moscov, 400 p. [in Russian].

5. Lytvyn, V. A. (2021). Vykhovannia u maibutnikh uchyteliv pochatkovoi shkoly vidpovidalnoho stavlennia do vzaiemodii z simieiu molodshoho shkoliara [Educating future primary school teachers to take a responsible attitude to interaction with the family of a primary school student]. Doctor's theasis. Kharkiv, 277 p. [in Ukrainian].

6. Petrenko, V. M. (2016). Metodyka vykhovnoi roboty $\mathrm{u}$ viiskovykh pidrozdilakh [Methods of educational work in military units]. Sumy, 475 p. [in Ukrainian].

7. Proiekt Ukazu Prezydenta Ukrainy "Pro kontseptsiiu viiskovo-patriotychnoho vykhovannia ta hromadskoho spryiannia bezpetsi i oboroni Ukrainy" [Draft Decree of the President of Ukraine "On the concept of militarypatriotic education and public assistance to the security and defense of Ukraine"]. Available at: https:// www.mil.gov.ua/ministry/normativno-pravova-baza/ gromadske-obgovorennya/57372/proekt-ukazuprezidenta-ukraini-pro-konczepcziyu/. [in Ukrainian].

8. Saienko, M. S. Modeliuvannia yak metod naukovoho piznannia, typy modelei [Modeling as a method of scientific knowledge, types of models]. Available at: http:/ /elib.umsa.edu.ua/bitstream/umsa/10711/1/ Modeluvannya_yak_metod_naykovoho_piznannya.pdf. [in Ukrainian].

9. Semenova, O. V. (2015). Pedahohichne modeliuvannia: funktsii ta skladovi [Pedagogical modeling: functions and components]. The scientific notes of Berdyansk State Pedagogical University: Coll. of Science. works. Vol. 3. Berdiansk, pp. 299-305. [in Ukrainian].

10. Teoretychni i metodychni zasady modeliuvannia fakhovoi kompetentnosti kerivnykiv zakladiv osvity [Theoretical and methodological principles of modeling the professional competence of heads of educational institutions]. Monohraf/ H. V. Yelnykova, O. I. Zaichenko, V. I. Maslov et al.; (Ed.).H. V. Yelnykova. Kyiv; Chernivtsi: Knyhy, 2010. 460 p. [in Ukrainian].

11. Fitsula, M. M. (2010). Pedahohika vyshchoi shkoly [Pedagogy of high school]. Tutorial. Kyiv, 456 p. [in Ukrainian].

12. Kharkivska, A. A. (2013). Modeliuvannia upravlinnia innovatsiinym rozvytkom pedahohichnoho VNZ [Modeling of management of innovative development of pedagogical high school]. The theory and methods of education management: electron. Science. profession.issue. Vol. 10. Available at: http://nbuv.gov.ua/ i-pdf/ttmuo $2013 \quad 10$ 47.pdf. [in Ukrainian].

13. Kharkivska, A. A. (2014). Systemnyi pidkhid ta innovatsii $\mathrm{v}$ suchasnii pedahohichnii nautsi [System approach and innovations in modern pedagogical science]. Mizhnarodnyi naukovyi visnyk: zb. nauk. st. za materialamy XXVII Mizhnar. nauk.-prakt. konf., Uzhhorod - Budapesht, 26-29 lystopada 2013 roku. International Scientific Bulletin: Coll. of Science. Art. on the Proceedings of the XXVII International. scientificpractical Conf., Uzhhorod - Budapest, November 26 29,2013(pp. 31-35). Vol. 8 (27). Uzhhorod. [in Ukrainian].

14. Shtoff, V. A. (1966). Modelirovanie i filosofiya [Modeling and philosophy]. Monograf. MoscovLeningrad, 303 p. [in Russian].

Стаття надійшла до редакції 20.04.2021

\section{G58080}

\section{“Серйозне прагнення до будь-якої мети - вже половина успіху в ї̈ досягненні". Вільгельм Тумбольдт німеиький бінлолог, фбілософб जs}

